\title{
Simulasi Gerak Osilasi Model Pegas Bergandeng Menggunakan Metode Runge-Kutta
}

\author{
Sigid Rahmatullah ${ }^{\mathrm{a}^{*}}$, Yudha Armana, Apriansyah ${ }^{\mathrm{b}}$
}

aProdi Fisika FMIPA Universitas Tanjungpura, Jl. Prof. Dr. Hadari Nawawi Pontianak

bProdi Ilmu Kelautan FMIPA Universitas Tanjungpura, Jl. Prof. Dr. Hadari Nawawi Pontianak

*Email : sigidrahmatullah19@gmail.com

(Diterima 24 November 2020; Disetujui 11 Desember 2020; Dipublikasikan 15 Desember 2020)

\begin{abstract}
Abstrak
Persamaan gerak sistem pegas bergandeng Fay dan Graham (2003) telah diselesaikan secara numerik untuk kemudian dibandingkan dengan hasil perhitungan analitik. Nilai kesebandingan didasarkan pada Symmetric Mean Absolute Percentage Error (SMAPE). Metode numerik utama yang digunakan untuk menyelesaikan persamaan gerak model pegas bergandeng adalah Runge-Kutta Orde Empat dan RungeKutta 45 Fehlberg sedangkan metode Leapfrog dan Euler digunakan sebagai metode tambahan uji. Ukuran langkah $h$ yang digunakan adalah 0,05 s. Berdasarkan hasil perhitungan dan nilai SMAPE yang diperoleh, Runge-Kutta 45 Fehlberg menjadi metode numerik dengan tingkat ketelitian yang paling baik diantara berbagai metode numerik yang digunakan pada konfigurasi sistem pegas hasil modifikasi model Fay dan Graham (2003) dengan variasi massa m, arah simpangan x, dan besar konstanta pegas k.
\end{abstract}

Kata kunci: pegas bergandeng, runge-kutta

\section{Latar Belakang}

Osilasi merupakan gerakan bolak-balik sebuah benda pada lintasan yang sama dan selang waktu tertentu [1]. Contoh dari penerapan konsep osilasi dalam dunia fisika adalah gerak harmonik sederhana menggunakan pegas. Ketika sebuah sistem dengan massa $m$ terikat pada ujung pegas diberi simpangan jarak $x$ kemudian dilepas, maka sistem bergerak bolak-balik di titik setimbang yang dipengaruhi gaya pemulih. Gerakan ini disebut gerak harmonik sederhana [2].

Model gerak harmonik pada pegas terbagi menjadi model sederhana dan teredam. Dalam model pegas teredam, pengaruh gaya gesek diperhitungkan sehingga gerak harmonik perlahan mengalami penurunan amplitudo. Pada model gerak harmonik sederhana, gaya gesek udara dan faktor hambatan diabaikan sehingga amplitudo dan frekuensinya tetap [3].

Analisis gerak harmonik dapat menggunakan perhitungan analitik ataupun numerik. Perhitungan analitik lebih mudah dilakukan pada model gerak harmonik sederhana, namun akan sulit jika model tinjauannya semakin kompleks. Hal ini disebabkan bentuk persamaan yang semakin rumit sehingga akan lebih efisien menggunakan solusi numerik dengan bantuan komputer dalam penyelesainnya [4]. Perhitungan numerik memiliki hasil yang hanya mendekati nilai sebenarnya, sedangkan untuk mendapatkan nilai yang sebenarnya harus menggunakan perhitungan analitik. Meskipun sulit, perhitungan analitik tetap diperlukan sebagai acuan dalam perbandingan antar metode.

Fay dan Graham (2003) telah melakukan penelitian gerak harmonik menggunakan model pegas bergandeng. Adapun model tersebut menggunakan dua buah pegas dan dua massa yang tergantung sebagai beban. Penyelesaian persamaan gerak dalam penelitian tersebut menggunakan perhitungan analitik untuk mengamati perubahan posisi simpangan terhadap waktu dari osilasi yang terjadi.

Penyelesaian persamaan osilasi terhadap gerak harmonik pada pegas bergandeng diteliti menggunakan metode numerik dan perhitungan analitik. Metode numerik yang digunakan yaitu Runge Kutta Orde 4 dan Runge Kutta Orde 45 Fehlberg. Selain itu, dilakukan uji banding tingkat akurasi Runge-Kutta dengan metode numerik lain seperti Euler dan Leapfrog. Hasil dari penyelesaian persamaan gerak secara numerik akan dibandingkan dengan perhitungan analitik mengacu pada jurnal Fay dan Graham (2003). Nilai kesalahan perhitungan terkecil baik itu pada perhitungan nilai posisi simpangan dan kecepatan yang diperoleh dari perbandingan metode tersebut akan menjadi model gerak harmonik pada pegas bergandeng yang dianggap lebih efektif. 


\section{Metodologi}

Model pegas bergandeng yang digunakan mengacu pada Fay dan Graham (2003) halaman 69 sebagai model osilator yang pertama. Model ini memiliki memiliki dua buah massa dan pegas. Besar massa pertama $m_{1}$ dan $m_{2}$ adalah $1 \mathrm{~kg}$, pegas pertama $k_{1}$ adalah $6 \mathrm{~N} / \mathrm{m}$, dan pegas kedua $k_{2}$ adalah $4 \mathrm{~N} / \mathrm{m}$, sedangkan simpangan benda pertama $x_{1}$ sebesar $1 \mathrm{~m}$ dan simpangan benda kedua $x_{2}$ sebesar $2 \mathrm{~m}$. Persamaan gerak yang digunakan adalah persamaan (1) dan (2).

$$
\begin{gathered}
x_{1}(t)=-\frac{k_{1}}{m_{1}} x_{1}\left(t_{i}\right)-\frac{k_{2}}{m_{1}}\left(x_{1}\left(t_{i}\right)-x_{2}\left(t_{i}\right)\right) \\
x_{2}(t)=-\frac{k_{2}}{m_{2}}\left(x_{2}\left(t_{i}\right)-x_{1}\left(t_{i}\right)\right)
\end{gathered}
$$

Pada perhitungan analitik, persamaan gerak (1) dan (2) diberi kondisi awal dengan $k_{1}$ sebesar 6 $\mathrm{N} / \mathrm{m}, k_{2}$ sebesar $4 \mathrm{~N} / \mathrm{m}, m_{1}$ dan $m_{2}$ sebesar $1 \mathrm{~kg}, x_{1}$ sejauh $1 \mathrm{~m}$, dan $x_{2}$ sejauh $2 \mathrm{~m}$ sehingga akan menjadi persamaan (3) untuk posisi simpangan benda pertama, persamaan (4) untuk kecepatan benda pertama, persamaan (5) untuk posisi simpangan benda kedua, dan persamaan (6) untuk menghitung kecepatan benda kedua. Perhitungan ini mengacu pada perhitungan Fay dan Graham (2003) [5].

$$
\begin{aligned}
& x_{1}(t)=\cos (\sqrt{2}(t)) \\
& v_{1}(t)=-\sqrt{2} \sin (\sqrt{2}(t)) \\
& x_{2}(t)=2 \cos (\sqrt{2}(t)) \\
& v_{2}(t)=-2 \sqrt{2} \sin (\sqrt{2}(t))
\end{aligned}
$$

Pada perhitungan metode numerik, persamaan (1) dan (2) diubah menjadi persamaan orde satu dengan bentuk sebagai berikut:

$$
\begin{aligned}
& f\left(v_{1}\right)=v_{1}(t) \\
& f\left(x_{1}\right)=-\frac{k_{1}}{m_{1}} x_{1}\left(t_{i}\right)-\frac{k_{2}}{m_{1}}\left(x_{1}\left(t_{i}\right)-x_{2}\left(t_{i}\right)\right) \\
& f\left(v_{2}\right)=v_{2}(t) \\
& f\left(x_{2}\right)=-\frac{k_{2}}{m_{1}}\left(x_{2}\left(t_{i}\right)-x_{1}\left(t_{i}\right)\right)
\end{aligned}
$$

\subsection{Metode Runge-Kutta}

Metode Runge-Kutta adalah metode yang umum digunakan dalam menyelesaikan persamaan diferensial biasa. Metode ini dianggap lebih teliti dari metode Euler [6]. Perhitungan pada metode Runge-Kutta memiliki empat evaluasi fungsi dalam sekali proses iterasi. Dari evaluasi fungsi tersebut, bentuk akhir persamaan Runge-Kutta Orde Empat untuk menghitung posisi dan kecepatan pada persamaan pegas bergandeng adalah sebagai berikut [7]:

$$
\begin{aligned}
& x_{1_{i+1}}=x_{1_{i}}+\frac{1}{6}\left(k_{1}+2 k_{2}+2 k_{3}+k_{4}\right) \\
& v_{1_{i+1}}=v_{1_{i}}+\frac{1}{6}\left(l_{1}+2 l_{2}+2 l_{3}+l_{4}\right) \\
& x_{2_{i+1}}=x_{2_{i}}+\frac{1}{6}\left(k_{1}+2 k_{2}+2 k_{3}+k_{4}\right) \\
& v_{2_{i+1}}=v_{2_{i}}+\frac{1}{6}\left(l_{1}+2 l_{2}+2 l_{3}+l_{4}\right)
\end{aligned}
$$

Dimana $x_{1_{i}}$ dan $x_{2_{i}}$ merupakan posisi benda pertama dan kedua di saat ke-i, sedangkan $v_{1_{i}}$ dan $v_{2_{i}}$ merupakan kecepatan benda pertama dan kedua di saat ke-i. Selain itu $k$ merupakan evaluasi fungsi dari kecepatan dan $l$ adalah evaluasi fungsi dari posisi.

\subsection{Metode Runge-Kutta Fehlberg}

Metode Runge-Kutta orde 45 Fehlberg atau Runge-Kutta Fehlberg merupakan modifikasi dari Runge-Kutta orde empat dan lima. Runge-Kutta Fehlberg memiliki enam evaluasi fungsi sehingga membuatnya semakin akurat. Dari evaluasi fungsi tersebut, bentuk akhir persamaan Runge-Kutta Fehlberg untuk menghitung posisi dan kecepatan pada persamaan pegas bergandeng adalah sebagai berikut [8]:

$$
\begin{aligned}
& x_{1_{i+1}}=x_{1_{i}}+\left(\frac{16}{135} k_{1}+\frac{6656}{12825} k_{3}+\frac{28561}{56430} k_{4}-\right. \\
& \left.\frac{9}{50} k_{5}+\frac{2}{55} k_{6}\right) \\
& v_{1_{i+1}}=v_{1_{i}}+\left(\frac{16}{135} l_{1}+\frac{6656}{12825} l_{3}+\frac{28561}{56430} l_{4}-\right. \\
& \left.\frac{9}{50} l_{5}+\frac{2}{55} l_{6}\right) \\
& x_{2_{i+1}}=x_{2_{i}}+\left(\frac{16}{135} k_{1}+\frac{6656}{12825} k_{3}+\frac{28561}{56430} k_{4}-\right. \\
& \left.\frac{9}{50} k_{5}+\frac{2}{55} k_{6}\right) \\
& v_{2_{i+1}}=v_{2_{i}}+\left(\frac{16}{135} l_{1}+\frac{6656}{12825} l_{3}+\frac{28561}{56430} l_{4}-\right. \\
& \left.\frac{9}{50} l_{5}+\frac{2}{55} l_{6}\right)
\end{aligned}
$$

\subsection{Metode Euler}

Metode Euler merupakan metode yang diambil dari dua suku pertama dari deret Taylor. Oleh karena itu, perhitungan metode ini sangat sederhana sehingga persamaan diferensial yang dikerjakan menjadi lebih mudah dan cepat. Namun, karena yang diambil hanya dua suku perhitungan paling kurang teliti diantara metode lainnya [6]. Bentuk persamaan dari metode Euler dituliskan sebagai berikut [9]:

$$
x_{1_{i+1}}=x_{1_{i}}+h v_{1_{i+1}}
$$




$$
\begin{aligned}
& v_{1_{i+1}}=v_{1_{i}}+h\left(-\frac{k_{1}}{m_{1}} x_{1_{i+1}}-\frac{k_{2}}{m_{1}}\left(x_{1_{i+1}}-x_{2_{i+1}}\right)\right) \\
& x_{2_{i+1}}=x_{2_{i}}+h v_{2_{i+1}} \\
& v_{2_{i+1}}=v_{2_{i}}+h\left(-\frac{k_{2}}{m_{2}}\left(x_{2_{i+1}}-x_{1_{i+1}}\right)\right)
\end{aligned}
$$

\subsection{Metode Leapfrog}

Metode Leapfrog merupakan ekspansi dari Metode Beda Hingga jenis beda tengah yang juga merupakan perluasan dari Deret Taylor [10]. Sama seperti metode numerik sebelumnya, untuk menghitung posisi dan kecepatan yang terjadi pada massa pertama dari sistem pegas bergandeng adalah sebagai berikut:

$$
\begin{aligned}
& x_{1_{i+1}}=x_{1_{i}}+h v_{1_{i+1}} \\
& v_{1_{i+1}}=v_{1_{i}}+\frac{1}{2} h\left(-\frac{k_{1}}{m_{1}} x_{1_{i+1}}-\frac{k_{2}}{m_{1}}\left(x_{1_{i+1}}-\right.\right. \\
& \left.\left.x_{2_{i+1}}\right)\right) \\
& x_{2_{i+1}}=x_{2_{i}}+h v_{2_{i+1}} \\
& v_{2_{i+1}}=v_{2_{i}}+\frac{1}{2} h\left(-\frac{k_{2}}{m_{2}}\left(x_{2_{i+1}}-x_{1_{i+1}}\right)\right)
\end{aligned}
$$

\subsection{Galat}

Nilai galat absolut merupakan selisih dari nilai aktual atau nilai sebenarnya $a$ dengan nilai pendekatan $b$ [11]. Symmetrical Mean Absolut Percentage Error atau SMAPE digunakan untuk menghindari penyimpangan perhitungan jika nilai aktual mendekati atau sama dengan nol. SMAPE dihitung berdasarkan persamaan berikut [12]:

$$
\begin{aligned}
& \varepsilon=a-b \\
& S M A P E=\frac{1}{n} \sum \frac{|a-b|}{(a+b) / 2}
\end{aligned}
$$

\section{Hasil dan Pembahasan}

Perhitungan persamaan gerak model pegas tunggal sangat mudah dihitung secara analitik. Namun, perhitungan ini akan mulai terasa sulit ketika model pegas mulai berubah dan dimodifikasi sedemikian rupa seperti model pegas bergandeng. Perhitungan persamaan gerak dari model yang lebih rumit seperti model pegas bergandeng akan lebih mudah diselesaikan bila menggunakan metode numerik. Meskipun hasil dari perhitungan metode numerik tidak akan sama persis dengan hasil perhitungan analitik, tetapi hasilnya akan mendekati perhitungan analitik.
Setiap metode numerik memiliki tingkat akurasi yang berbeda, sehingga dalam perhitungannya akan menghasilkan nilai kesalahan hitung atau nilai galat. Semakin kecil nilai kesalahan hitung, berarti akurasi dari metode tersebut semakin meningkat. Perhitungan persamaan gerak pegas bergandeng model Fay dan Graham (2003) yang pada penelitian sebelumnya dikerjakan secara analitik, saat ini telah disimulasikan dan dihitung dengan berbagai metode numerik. Nilai kesalahan hitung dari setiap metode numerik dapat dilihat di Tabel 1.

Tabel 1. Nilai SMAPE simpangan dan kecepatan pada kedua benda di sistem pegas bergandeng model Fay dan Graham (2003) dengan ukuran langkah $h$ sebesar $0,05 \mathrm{~s}$.

\begin{tabular}{lcccc}
\hline & $x_{1}$ & $x_{2}$ & $v_{1}$ & $v_{2}$ \\
\hline Runge- & 0,0004 & 0,0004 & 0,0006 & 0,0005 \\
Kutta & 56406 & 49672 & 38691 & 13870 \\
Orde & 2419 & 063 & 531 & 561 \\
empat & & & & \\
\hline Runge- & 0,0000 & 0,0000 & 0,0000 & 0,0000 \\
Kutta & 00124 & 00124 & 00164 & 00164 \\
Fehlberg & 06 & 0601 & 8563 & 8563 \\
\hline \multirow{2}{*}{ Euler } & 1,1652 & 1,2580 & 1,1359 & 1,1999 \\
& 00173 & 06681 & 20309 & 23754 \\
& 1062 & 0782 & 4835 & 7845 \\
\hline \multirow{3}{*}{ Leapfrog } & 0,0962 & 0,1605 & 0,1103 & 0,1618 \\
& 12204 & 14902 & 01446 & 28921 \\
& 1727 & 0942 & 7254 & 7576 \\
\hline
\end{tabular}

Pada Tabel 1, dari hasil perhitungan nilai kesalahan hitung didapat Rung-Kutta Fehlberg memiliki nilai yang lebih kecil daripada metode yang lain. Hal ini menempatkan metode ini sebagai metode yang memiliki akurasi yang lebih tinggi daripada metode yang lain. Sebaliknya, berdasarkan Tabel 1, metode Euler memiliki nilai kesalahan hitung yang lebih besar dan menjadi yang tidak akurat.

Bentuk osilasi berdasarkan nilai posisi simpangan benda beserta kecepatan menggunakan metode numerik dan perhitungan analitik dapat dilihat pada Gambar 1 dan Gambar 2. Pada Gambar 1, perhitungan dan bentuk grafik posisi simpangan terhadap waktu dapat dilihat amplitudo berkisar dinilai $1,0 \mathrm{~m}$ dan $-1,0 \mathrm{~m}$ sedangkan bentuk osilasi yang terjadi adalah osilasi harmonik. Hal yang sama juga terjadi di Gambar 2 di mana posisi simpangan berkisar di nilai 2,0 m dan -2,0 m. Jika dilihat lagi pada kedua gambar, ada satu bentuk gelombang yang tidak sama. Bentuk tersebut merupakan hasil dari perhitungan metode 
Euler. Hal ini terjadi karena metode Euler hanya menggunakan dua suku pertama dari Deret Taylor tanpa mempertimbangkan suku-suku lain setelahnya, sehingga perhitungan menjadi lebih cepat namun mengurangi akurasi dari hasilnya.

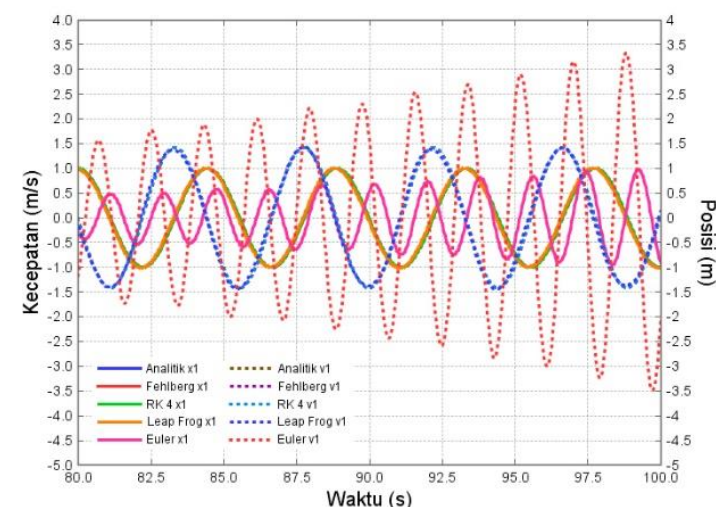

Gambar 1. Simpangan dan kecepatan benda pertama pada sistem pegas bergandeng model Fay dan Graham (2003) dengan ukuran langkah $h$ sebesar 0,05 s di detik ke 80 hingga 100.

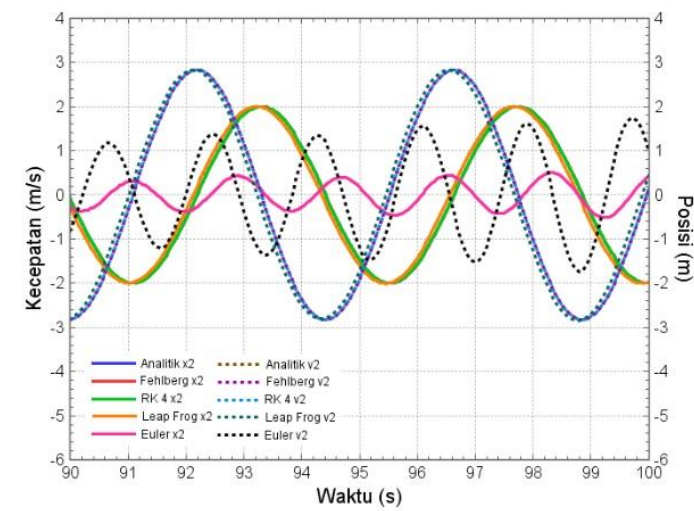

Gambar 2. Simpangan dan kecepatan benda kedua pada sistem pegas bergandeng model Fay dan Graham (2003) dengan ukuran langkah $h$ sebesar 0,05 s di detik ke 90 hingga 100 .

Bentuk osilasi harmonik yang dihasilkan dari perhitungan empat metode numerik (Analitik, Runge-Kutta Orde 4, Runge-Kutta Fehlberg, dan Leapfrog baik untuk nilai posisi simpangan benda maupun kecepatan benda meskipun terlihat saling berhimpit, namun jika dilihat lebih dekat maka akan terlihat keempatnya memiliki selisih nilai. Hal ini disebabkan masing-masing metode numerik memiliki nilai keakuratannya tersendiri. Perhitungan analitik menjadi acuan dalam menentukan akurasi metode numerik yang diuji. Berdasarkan Tabel 1, metode Euler menjadi yang paling tidak akurat dengan nilai SMAPE pada posisi simpangan sebesar 1,165. Metode numerik dengan akurasi paling tinggi adalah Runge-Kutta 45 Fehlberg dengan nilai SMAPE sangat kecil sebesar 1,2406 x 10-7, diikuti Runge-Kutta Orde 4 sebesar 4,564 x 10-4, dan Leapfrog sebesar 9,6212 x 10-2. Hal ini juga terjadi pada perhitungan posisi simpangan benda kedua dimana nilai SMAPE metode Euler sebesar 1,258, lebih tinggi dari nilai metode numerik yang lain.

Pada Gambar 1 dan Gambar 2, ketika kedua benda yang disimpangkan dilepas, maka akan terjadi perubahan posisi sehingga menghasilkan kecepatan. Kecepatan kedua benda akan terus bertambah hingga benda berada di titik setimbang 0,0 m. Saat benda melewati titik setimbang, kecepatan benda perlahan-lahan menurun hingga bernilai $0,0 \mathrm{~m} / \mathrm{s}$ sedangkan benda berada di puncak simpangan. Pada saat benda di puncak simpangan, benda mengalami keadaan henti sesaat, kemudian gaya pemulih pada sistem akan bekerja untuk memberi dorongan benda kembali ke lintasan osilasi. Hal ini akan terjadi secara terus menerus tanpa henti karena tidak ada gaya lain yang bekerja pada sistem yang berperan sebagai gaya hambat.

\section{Kesimpulan}

Nilai kesalahan perhitungan atau nilai SMAPE yang diperoleh metode Runge-Kutta Fehlberg lebih kecil daripada metode Runge-Kutta orde 4, Leapfrog, dan Euler sehingga metode Runge Kutta Fehlberg lebih teliti daripada metode numerik lain yang ikut diujikan.

\section{Daftar Pustaka (Style: Heading Pustaka)}

[1] D. Halliday, R. Resnick dan J. Walker, Fisika Dasar, Jakarta: Erlangga, 2010

[2] P. A. Tipler dan G. Mosca, Physics for Scientists and Engineers, New York: W. H. Freeman and Company, 2008.

[3] G. C. King, Vibrations and Waves, Chichester: Wiley, 2009.

[4] N. Mufidah dan A. Prihanto, Analisis Sistem Pendulum Sederhana Teredam dengan Simulasi Menggunakan Bahasa Pemrograman Delphi 7.0," Jurnal Fisika, 2(1), pp. 1-5, 2013.

[5] T. H. Fay dan S. D. Graham, Coupled Spring Equations, International Journal of Mathematical Education in Science and Technology, 34(1), pp. 65-79, 2003.$]$ 
[6] B. Triatmodjo, Metode Numerik Dilengkapi dengan Program Komputer, Yogyakarta: Beta Offset, 2012

[7] X. Yang dan Y. Shen, Runge-Kutta Method for Solving Uncertain Differential Equations, Journal of Uncertainty Analysis and Applications, 3(17), 2015.

[8] R. N. Darmawan dan R. M. Hariastuti, Analisis Simulasi Solusi Numerik Model Lotka-Volterra dengan Metode Runge- Kutta Fehlberg, Kubik, 3(2), pp. 100-106, 2018.

[9] S. Suparno, Komputasi untuk Sains dan Teknik: Dalam Matlab, 3 penyunt., Jakarta: Universitas Indonesia, 2007.

[10] Alman, Simulasi Komputasi pada Transport Polutan 2 Dimensi dengan Menggunakan Skema Beda Hingga Leapfrog, Jurnal IT, 9(1), pp. 71-76, 2018.

[11] S. C Chapra dan R. P. Canale, Numerical Methods for Engineers, New York: Mc GrawHill Education, 2015.

[12] C.Tofallis, A Better Measure of Relative Prediction Accuracy for Model Selection and Model Estimation, Journal of The Operational Research Society, 66(8), pp. 1352-1362, 2015. 